Original scientific article

UDC: 614.2(469)"1933/1969"

364.69(469)"1933/1969"

DOI: $10.25106 / \mathrm{ahm} .2017 .0211$

\author{
Andreia da Silva Almeida \\ School of Arts and Humanities, University of Lisbon \\ Alameda da Universidade MB, 1600-21, Lisbon, Portugal \\ E-mail: phd_historia@sapo.pt
}

\title{
SALAZARISM, MOTHERHOOD AND CHILD HEALTHCARE: IDEOLOGY AND PUBLIC POLICIES
}

\begin{abstract}
During Salazar's Estado Novo, Portuguese health policies were a reflex of general policies of the dictatorial regime. The crisis during World War II and the 1958's electoral storm, improved the development of the state's health sector. However, in the mother and child healthcare field, the regime's ideology was not consistent with its political practice. Ideologically, the Estado Novo assumed a natalist, conservative and catholic position, condemned abortion, contraception and the woman's work outside the home. The Portuguese women, single or married, should be confined to domestic work. For moral and economic reasons, the regime defended home birth, in a minimalist conception of healthcare. Medically assisted births, in hospitals, were mainly provided to mothers for families of low income or problematic births. This selfproclaimed family defender, Salazar's Estado Novo revealed a considerable disinterest and lack of investment in mother and child healthcare, evidenced by statistical and budgetary sources. Both the lack of interest and policies are, also, documented by the high child and maternal mortality rates, two of the highest European indicators at this level. In fact, the health sector was always depending on donations for charity and private organizations, although the regime proclaimed its focus on mother and child healthcare. These political options as well as the high mortality rates attest the misleading propaganda of a family defender regime. In the sixties, political, social and mentality changes, that occurred in Portugal, forced a more dominant position of the state in the health sector. However, the state'srole in mother and child healthcare sector remained poor. Mother and child healthcare still depending on private institutions, essentially from charity.
\end{abstract}

\footnotetext{
* This paper is a part of a doctoral thesis, entitled "The Health in Salazar's Estado Novo (1933-1968): Policies, Systems and Structures", a scientific-research project financed by Portuguese National Funding Agency for Science, Research and Technology - SFRH/BD/80442/2011
} 
Keywords: maternal mortality, Portugal, health care sector, health policy, child mortality

\section{Introduction}

During the Salazar's Estado Novo the main purpose of the family was procreation, thus being strongly against any form of contraception. The regime's ideology regarding life and reproduction was in line with the Catholic Church, the state's official religion. The Estado Novo was therefore, related to natality, thus encouraging the cult of large families, hence developing from the 1930s, a clear propaganda activity for that matter [1]. Natality was a common position in authoritarian regimes during the 1930s. In Spain, during Franco's regime, the demographic interest was not an illusion, where you could observe a parallelism with Mussolini's fascist Italy and, in a way, the ideas expressed by Hitler's National-Socialist Party [2].

Family was considered the base cell of the Estado Novo society, one of the pillars of the regime, being part of the pentagram of its true basis - God, Motherland, Family, Authority and Work - proclaimed by Salazar in 1936, during a commemoration speech of the National Revolution. As stated in the 1933 Constitution, articles 12 and 14, family was one of the pillars of the social framework and economic policy, constitutionally elected as the primary basis of education, discipline and social harmony, "the source of conservation and race development", and the basis of political and administrative order [3].

During the Estado Novo, women had a core position in the family. Therefore, the regime didn't lightly accept women participation in the work force, for not only would that reduce natality, as it could increase child mortality, thus causing order disruption of the society. This belief was indeed present in the Iberian regimes, such as in Spain, were mothers were considered guilty for child mortality high rates, instead of admitting the regime's ignorance in new-born care [1]. In Portugal, however, you wouldn't see a direct culpability of mothers, although that guilt was indirectly present, and its ignorance the purpose of a propaganda campaign well managed by the regime, to educate women for the proper fulfilment of their "motherhood duties".

The regime made it clear that the family wellbeing was sometimes contradicted by using maternities, hospitals and day care schools. Moreover, "it is not favourable to the family wellbeing, the systematic hospital admission of mothers, during pregnancy or for giving birth", because "abandoning your Home, even if temporary, will frequently infer in serious disadvantages for the moral integrity of the family" [3]. The Estado Novo thus valued home birth, for moral reasons, but at the same time supported minimal home assistance, justifying that maternities could be abusively used by the people. Who should, then, resort to maternities? According to Act 9/ III of the Corporative Hall,only women whose birth was considered difficult or with higher risk factors, or women that had no home of their own, or whose home didn't have the proper sanitary and moral conditions [4]. 
From the structural point of view, maternities in Portugal, were developed within the scope of underprivileged mother and child salvation speech, of humanitarian and political motive, serving a natality policy. The privileged classes in the beginning of the XX Century, had a certain aversion to hospital birth, given hospital's bad reputation before the microbiologic discoveries of aseptic practises, where the risk of severe infections and death, both of mother and child, was extremely high. Consequently, the resurgence of maternities in our country was late and, during its initial stage, it was mainly directed to underprivileged classes. During the first decades of the XX Century, midwifes and midwife-doctors, acting independently, were the main support in case of more specialized necessity, considering that most of the population would resort to the "curiosas", traditional birth attendants in rural areas, where subsistent economics were based on the exchange of goods and services, didn't allow the payment of specialized resources [1].

Throughout the 1930s, maternities went from shelters for underprivileged mothers to becoming centres of promotion and orientation for mother-child assistance, intervening during pregnancy and puerperium and not only during birth, and whose preventive actions aimed at "protecting and improving the fruits of human descendance". The assistance given in maternities had, therefore, a doctor-social purpose, through the "correction of economic and moral deficiencies" [1], that resulted in the abandonment of the basic rules of hygiene and to the lack of accountability the family members. However, these institutions goal, was also one of scientific research, developing obstetric and gynaecologic hospitalization services, and an external service of medical appointments within the same area of expertise.

Other excellence structures for mother-child support were the milk dispensaries. During the $1^{\text {st }}$ Republic there was a resurgence of these institutions. The Association for the Protection of the First Infancy, founded in 1901, paved the way for the first of several dispensaries in 1903. During the 1920s, would be created in Lisbon 5 municipal milk dispensaries. In a completely different panorama, in the rural areas there were no such institution, where the so called "nursing nannies" were used [5]. The milk dispensaries created by the Association for the Protection of the First Infancy had a milk service, responsible for hygienic milk production, supervised by veterinarians, a service where milk was distributed for free, on a daily basis,to mothers that could not breast feed, as well as a weekly infant medical care and a social service [6].

However, in 1937, the statistical yearbooks abandoned the designation "milk dispensary" to create a new paradigm of "childcare service provider" institutions, a designation that seems to increase the support scope of these institutions that, in fact, not only provide milk, but also other medical healthcare and support, such as vaccination. Between 1933 and 1937, the majority of these baby care nurseries were situated in the big cities of Lisbon and Oporto. However, in other Country Districts, these institutions did not exist at all. 
Considering the above political and ideological options from the regime, we will try to peer, throughout this study, the results obtained from the point of view of the key sanitary indicators: Infant Mortality Rate and Mother Mortality Rate. Also, we will try to understand whether other factors such as, sector structural evolution, evolution of other sanitary sub-systems and organic and legislative evolution were in fact key for the development of this type of assistance.

\section{Methods}

The methodology used in this study is based on critical analysis of sources and bibliography. Regarding the sources used, we must refer to the statistical references, essential in the evaluation of the true dimension of the key sanitary indicators produced. The most important sources, at this level, are included in the Portuguese Statistics Yearbook, under the responsibility of the Historic Archive of the National Statistics Institution. Also, both the access to the OCDE Historic Archive and the B.R. Mitchel publication, named European Historical Statistics (1750-1970), was of major importance for it allowed the comparison with international data. There are, however, other sources of extreme importance considered in this study, namely a great variety of legislative and budget sources, as well as the access to periodic publications of the regime and its sectors related to healthcare.

From the chronological point of view, the work covers the years between 1933 and 1968, corresponding the Salazar's government as President of the Ministers Council. The statistical data were evaluated through a sample from odd years. The study focuses on the Portuguese continental territory, and does not include the autonomous regions and Portuguese colonies.

\section{Results}

As previously stated, and in an initial stage, the regime supported home childbirth, with hospitals being used solely for pregnant women of low income, or for the most problematic cases: going from the social-medical maternity functionality paradigm to an essentially clinical paradigm. The Conservative and the Catholic groups with influence in politics, believed child-birth should take place at home - the "family sanctuary". Hospital child-birth could cause "lack of family sharing, the alienation of the husband from the suffering that came with giving birth, and the contact with women of bad conduct" [1].

As for the places were births took place, we managed to gather statistical data from 1947 to 1969. Through this data, we concluded that during this period, hegemonically, births occurred at home instead of at hospital. However, from the beginning of the 1960s, home birth was staring to lose ground, as opposed to the growing numbers of child-birth in hospitals. Nevertheless, home child-birth was always hegemonic during this period [7]. 


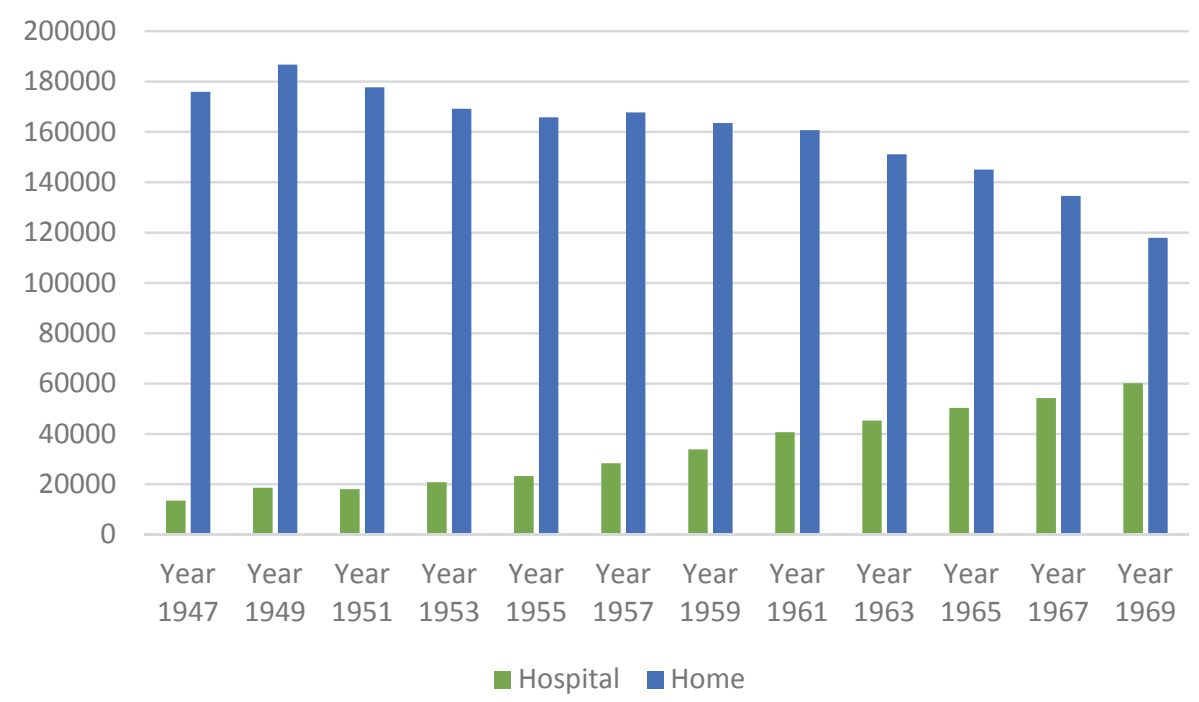

Graphic 1: Places where births occurred (1947-1969)

[Source: Portuguese Statistics Yearbooks (1947-1969)].

Strangely, the statistical data suggest a higher percentage of stillborns born in hospitals, when compared with home child-birth. This trend would lower between 1955 and 1969, but would still be quite expressive during this period. Also, data shows that the stillborns percentage is higher on home child-birth with medical assistance, than when compared with child-birth assisted by nurses, without any kind of assistance or in inadequate places [7].

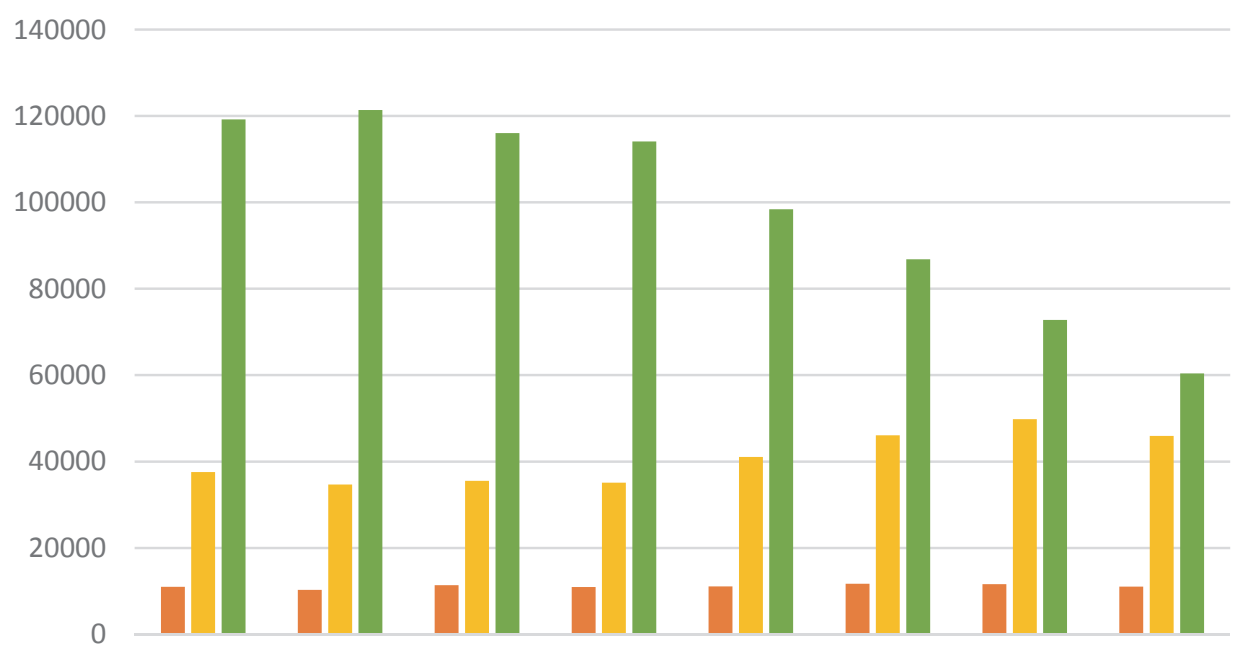

Year 1955 Year 1957 Year 1959 Year 1961 Year 1963 Year 1965 Year 1967 Year 1969

With medical assistance $\quad$ With midwife assistance $\quad$ Without assistance

Graphic 2: Home birth assisted (1955-1969), per total of births

[Source: Portuguese Statistics Yearbooks (1955-1969)]. 


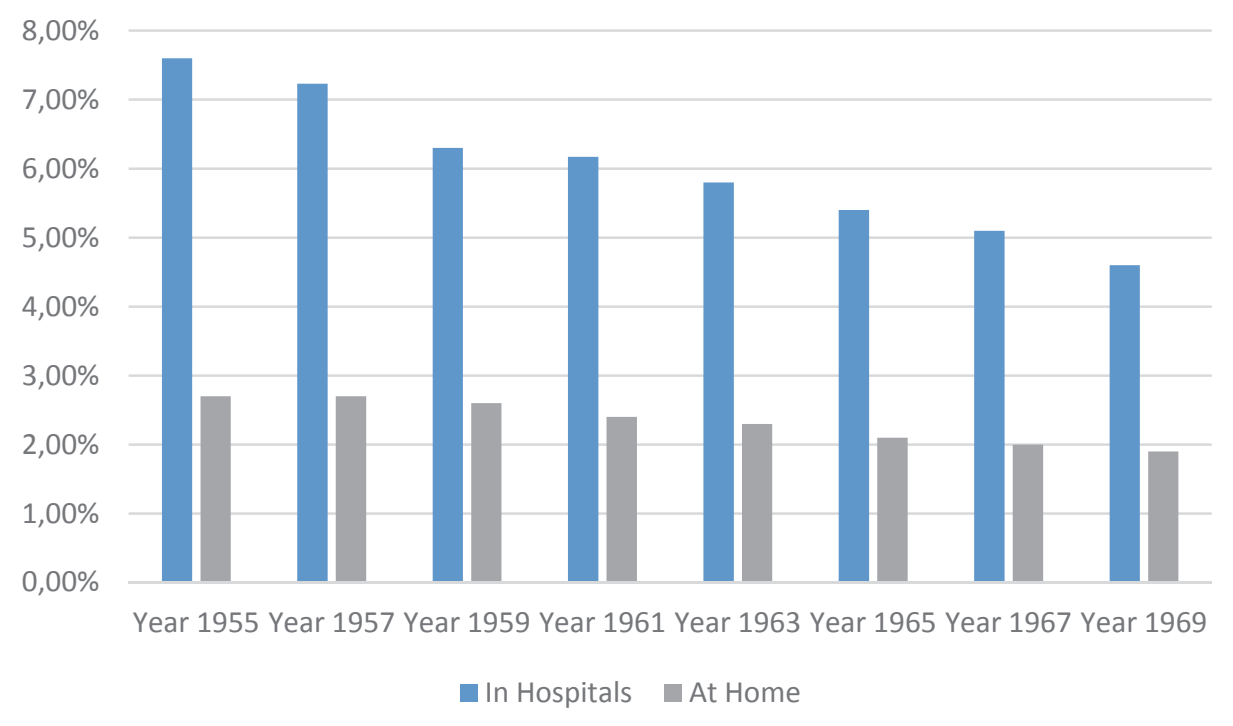

Graphic 3: Percentage of stillborns per type of birth (1955-1969)

[Source:Portuguese Statistics Yearbooks (1955-1969)].

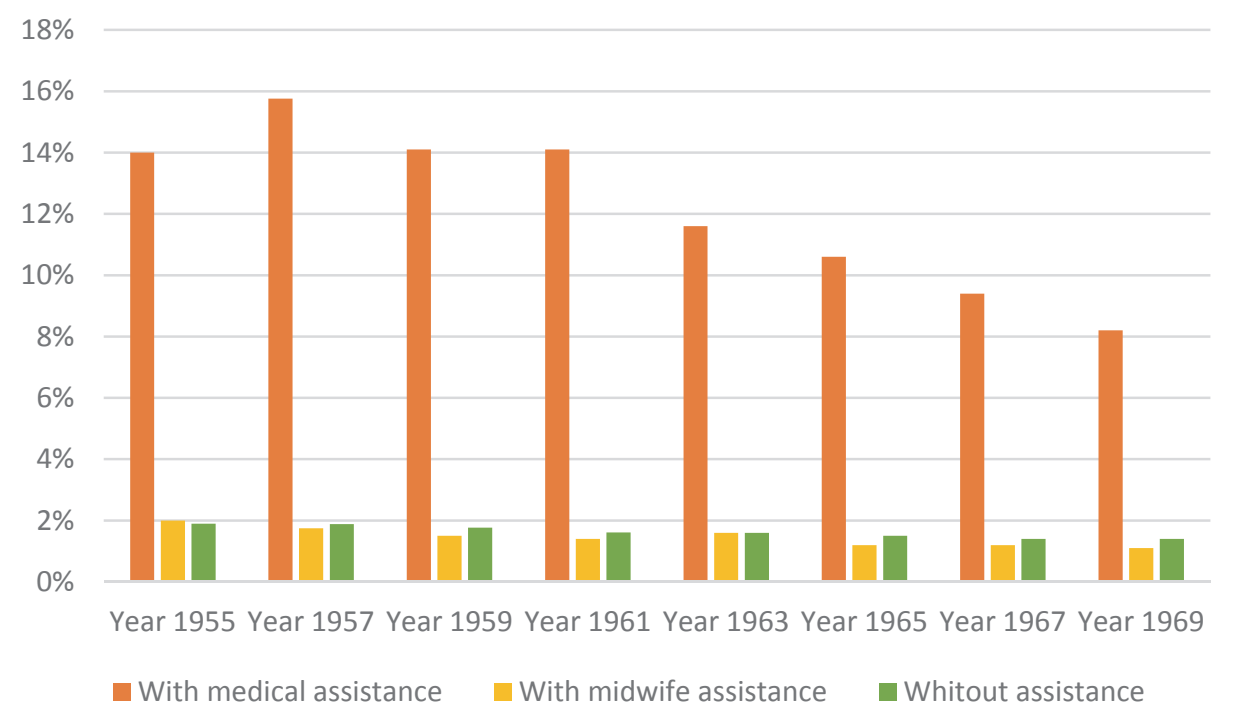

Graphic 4: Percentage of stillborns according to type of assistance in home births (1955-1969)

[Source: Portuguese Statistics Yearbooks (1955-1969)].

From the system framework evolution point of view, the statistical data show us in fact a trend in the increase of maternities and birth infirmaries within the Portuguese territory during the first years of the Estado Novo. This increase was more evident from 1937, being clearly expressed from 1943 on. In 1931 there were only 30 establishments throughout the country, as opposed to 1945 where there were already 
106 , corresponding to an increase of these institution of $353 \%$ during a period of 15 years [7].

This increase seemed consolidated until the year 1955, from when the numbers don't allow us to take more conclusions. We can see a decrease in statistical data from that year, since there was no counting of maternities and infirmaries - from that year on, only the maternities were considered in the statistics.

As previously mentioned, from 1957, the statistical counting didn't consider the birth infirmaries and maternities together. Meaning that, since 1957, we can prove that the residual number of maternities in relation to birth infirmaries, the latter being much higher and spread throughout all districts, as opposed to maternities. Maternities were an amenity present in less than half of the Portuguese districts. In 1957 , the number of maternities was less than $12 \%$ of the total number of establishments oriented for these type of medical assistance [8].

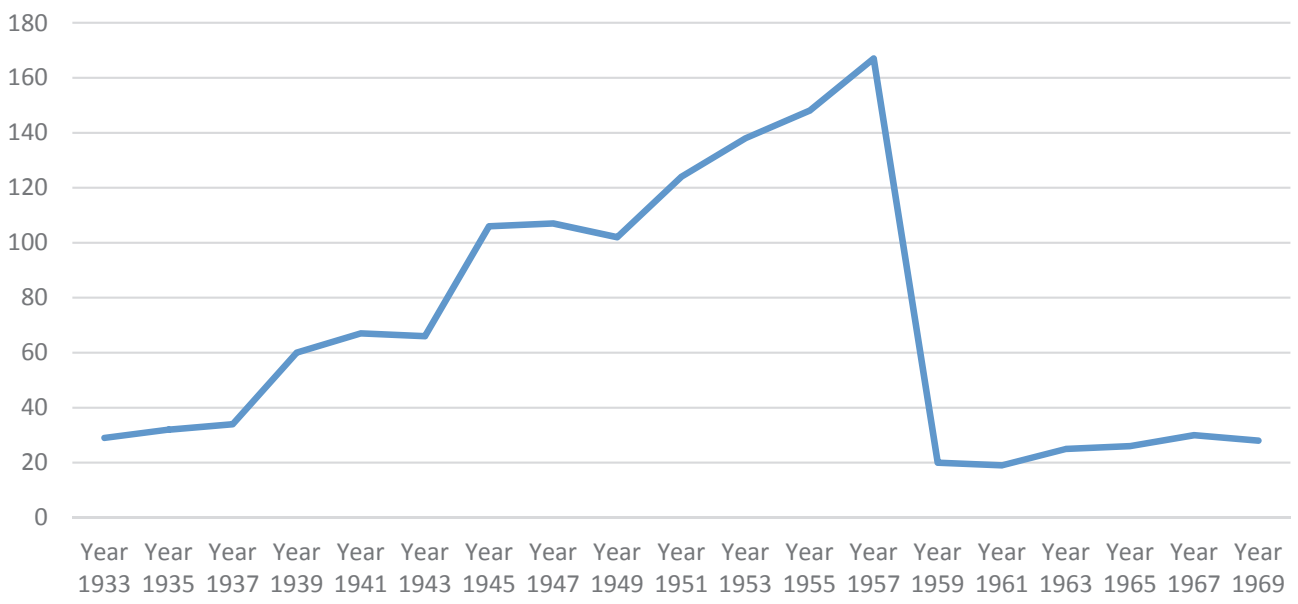

Graphic 5: Evolution of the total of maternities and birth infirmaries in Portugal (1931-1969)

[Source:Portuguese Statistics Yearbooks (1933-1969)].

In regard to the patrimonial dependency of the institutions, we have data from 1945 to 1967, with a gap of a decade between 1949 and 1959 [9]. Between 1945 and 1949, the statistical counting covered both maternities and birth infirmaries, as opposed to the following years. These data state that, most assisted births in a hospital environment, were performed in birth infirmaries part of the Charity hospitals, where the State had only a small presence, at least up until 1949. By looking at the 1959 data, with a gap of a decade and only concerning the number of maternities, most of these institutions were private, followed by institutions part of corporations. In fact, during the 1960s, the number of these institutions grew, either part of the state or corporations, although the data clarifies that birth infirmaries were a structure preferred by most women all over the country. 
In the Intercalate Fomenting Plan for1965-1967, the government recognized that "some" activities of mother-child protection were under the responsibility of private entities, thus the help from the state was given mainly to maternities and birth infirmaries that were not part of central hospitals. Only the central maternities and the mother-child dispensaries belonged to the State [10]. In the III Fomenting Plan, the regime wanted to use the extra beds in sub-regional hospitals for small "rural maternities" that were being created [11].

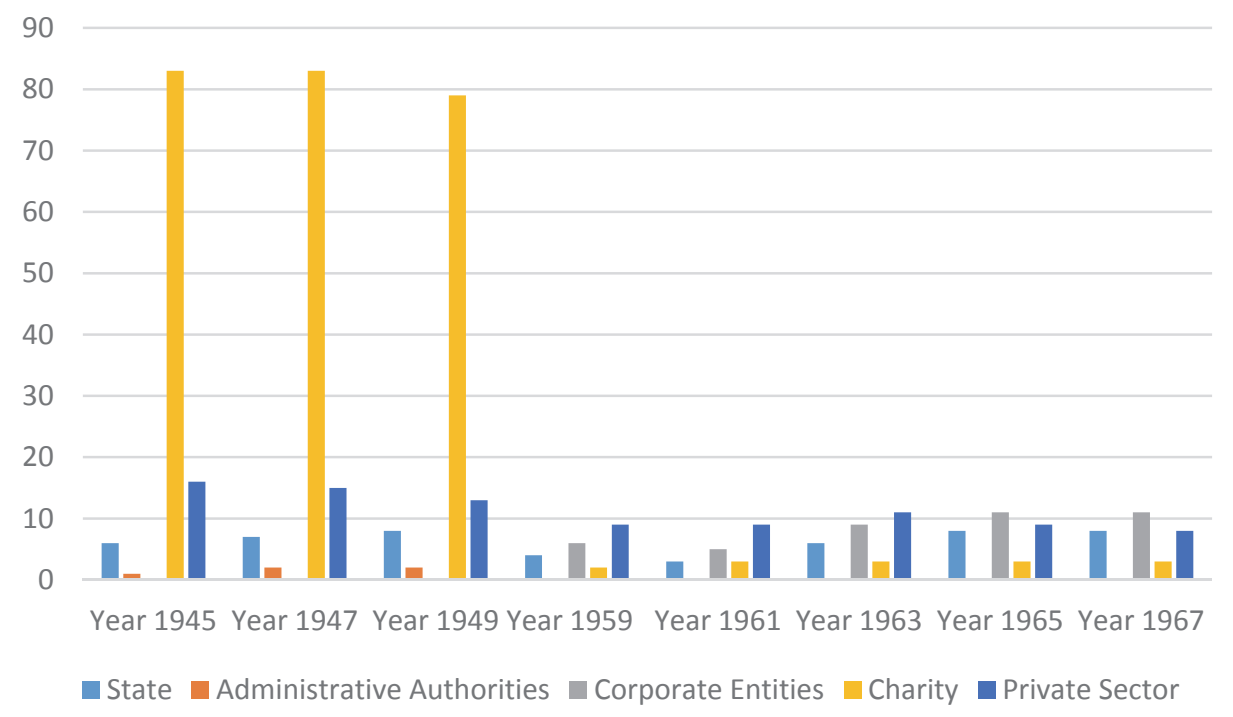

Graphic6: Maternities and birth infirmaries patrimonial dependency (1945-1967) [Source: Portuguese Statistics Yearbooks (1945-1969)].

What better than health indicators for us to evaluate success or failure of certain political orientations in this area. Infant mortality is considered one of the key indicators to evaluate a community health state. Improvement in food and nutrition, housing and working conditions, and of the life of the population in general, as well the education level of mothers, are the key factors involved in the reduction of infant mortality rates registered in European countries during their demographic and sanitary transition processes [12].

By analysing the infant mortality rate indicator, "the most secure indicator for the success and prosperity of a nation" [13], during Salazar's political period, we need to take one first basic conclusion: the Estado Novo, in 36 years, managed to lower the infant mortality rate by $93 \%$. In 1969 , infant mortality rate was less than half than the one registered in 1933. We can see a clear drop in this indicator in the beginning of the 1940s that went on to the beginning of the 1950s. During the 1950s the indicators were stationary and from 1960 until the end of the regime these indicators broke down again [14]. 


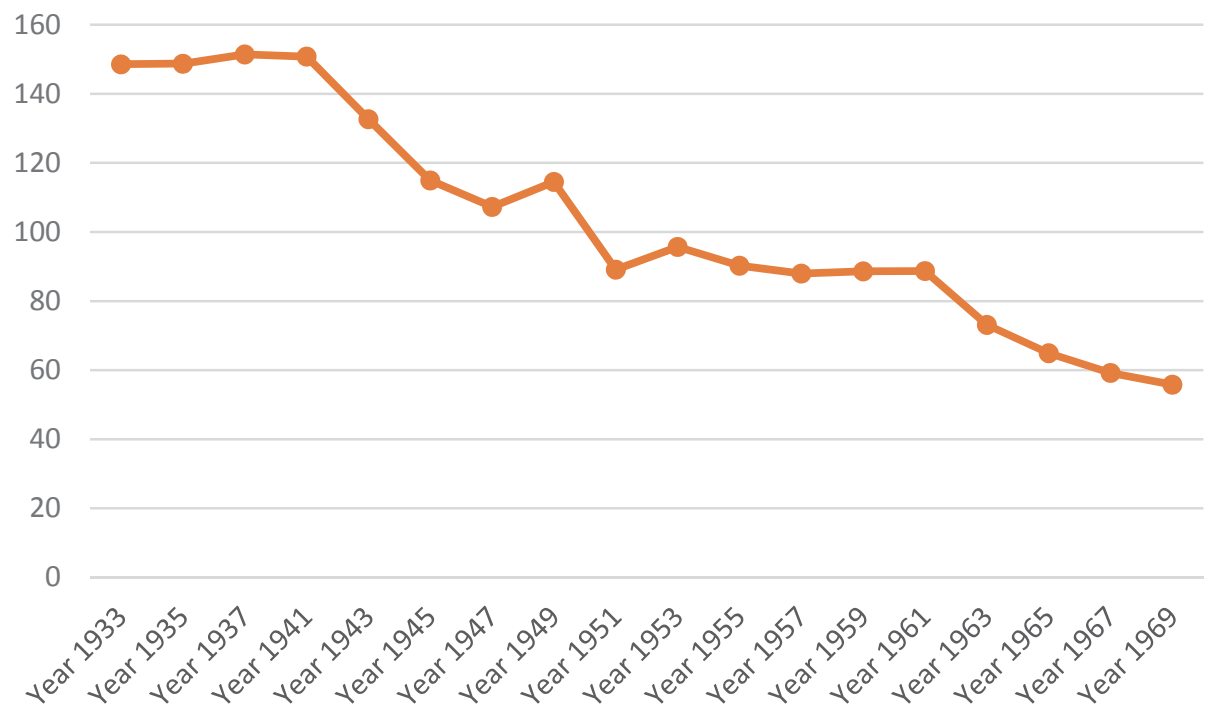

Graphic 7: Evolution of infant mortality rate in Portugal (1933-1969), per mileage. [Source: Portuguese Statistics Yearbooks (1933-1969)].

In the beginning of the 1940s, this health indicator seems to show the growth in the number of institutions of maternity assistance - maternities, birth infirmaries, dispensaries, baby care nurseries - as well as a growing collaboration of the Charities in providing these services. During the 1940s, we see a steep decrease of this indicator, despite the unfavourable context of WWII, were crises, unemployment, poverty and social misery thrived. However, as we stated before, the regime reacted to social uprising by ensuring popular measures of political, organic and financial reorganization of the assistance and health services, and to a development of a concomitant social services, that proved to be a positive evolution. Health policy was no more than a political chapter in general, reflecting its successes and drawbacks.

Nevertheless, it's impossible to evaluate the Portuguese infant mortality, without establishing a comparison with some European countries. Therefore, we resorted to statistical data of some countries - Germany (GDR; GFR), United Kingdom, Spain, France, Bulgaria, Yugoslavia, Greece, Italy, Poland, Romania, Albania, Norway, Poland, Switzerland and Holland [15] - to try and evaluate them. During the first years of the regime, before WWII, Portugal was one of the European countries with the highest infant mortality rate, only surpassed by some eastern countries such as Romania and Bulgaria. With regards to southern Europe, Portugal had the highest infant mortality rate, practically double of the one registered in France in 1941, and that of Spain in the post-civil war.

Regarding the post WWII period, Portugal was still one of the European countries with the highest child mortality rate. Up until the mid-1950s, the Portuguese child mortality rate would only be surpassed by eastern countries such as Albania, Romania, Bulgaria and Yugoslavia. However, in other communist countries like Sta- 
lin's USSR, Poland or GDR, the child mortality rates were considerably lower than the Portuguese.

From the end of the 1950s, most of the eastern countries had significantly reduced their child mortality rate. Portugal was only surpassed, at this level, by Yugoslavia. The Portuguese incapacity to reduce this key sanitary indicator was even more visible in the beginning of the 1960s. By then, Portugal was probably the European country with the highest child mortality rate, surpassing all the communist countries of the East, USSR and GDR, and at the same level as Tito's Yugoslavia. From 1963, Portugal would only be surpassed by Albania.

At an Iberian level, the Portuguese child mortality rate was, during the 1960s, twice as high as the one in Spain. In 1969, the Portuguese child mortality rate was double than the one in G.D.R., United Kingdom, Spain, France and Italy, four times higher than Holland, Norway, Switzerland and nearly double the rates in countries like Poland, Greece and Bulgaria.

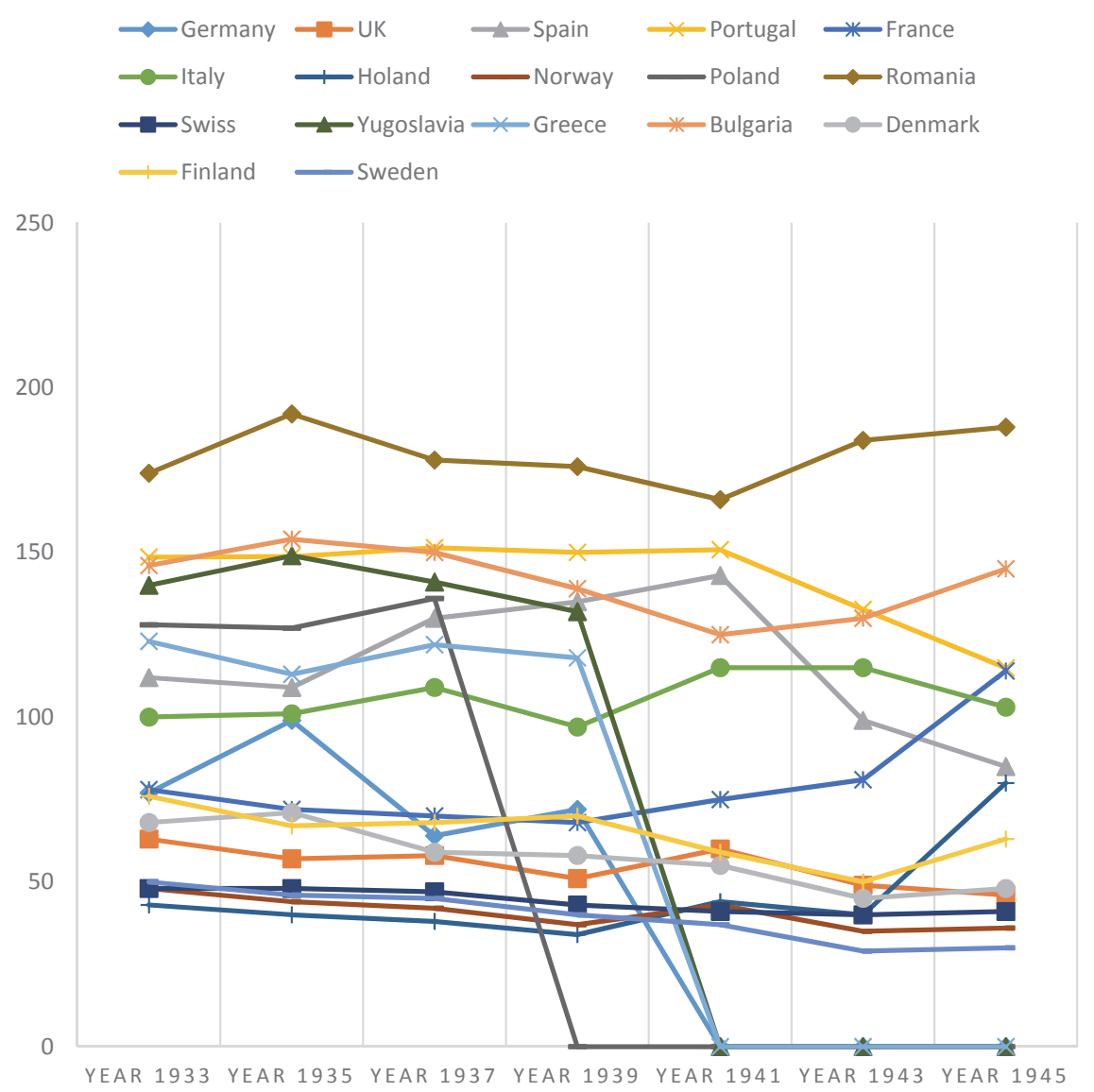

Graphic8: Compared evolution of child mortality rate in several European countries (1933-1945) - per mileage,

[Source: B.R. Mitchell.European Historical Statistics 1750-1970]. 
Table 1:Compared evolution of child mortality rate in several European countries (1947-1969) - per mileage, according to B.R. Mitchell. [ALB: Albania; GFR: German

Federal Republic, GDR: German Democratic Republic; UK: United Kingdom; SP:

Spain; PT: Portugal; FR: France; IT: Italy; HL: Holland; NRG: Norway; POL: Poland; RMN: Romania; USSR: Soviet Union; SW: Switzerland; JGL: Yugoslavia],

[Source: B.R. Mitchell.European Historical Statistics 1750-1970].

\begin{tabular}{|c|c|c|c|c|c|c|c|c|c|c|c|c|c|c|c|}
\hline & ALB & GFR & GDR & UK & SP & PT & FR & IT & HL & NRG & POL & RMN & USSR & SW & JGL \\
\hline $\mathbf{1 9 4 7}$ & 0 & 86 & 114 & 39 & 71 & 107,26 & 71 & 84 & 34 & 35 & 0 & 200 & 0 & 39 & 0 \\
\hline $\mathbf{1 9 4 9}$ & 0 & 60 & 78 & 32 & 69 & 114,5 & 60 & 74 & 27 & 28 & 107 & 136 & & 34 & 102 \\
\hline $\mathbf{1 9 5 1}$ & 124 & 53 & 64 & 30 & 63 & 89,1 & 50 & 67 & 25 & 26 & 115 & 118 & 84 & 30 & 140 \\
\hline $\mathbf{1 9 5 3}$ & 100 & 47 & 54 & 27 & 53 & 95,68 & 42 & 58 & 22 & 22 & 88 & 96 & 68 & 30 & 116 \\
\hline $\mathbf{1 9 5 5}$ & 104 & 42 & 49 & 25 & 51 & 90,24 & 39 & 51 & 22 & 21 & 81 & 78 & 60 & 26 & 113 \\
\hline $\mathbf{1 9 5 7}$ & 87 & 37 & 46 & 23 & 47 & 87,97 & 34 & 50 & 18 & 21 & 77 & 81 & 45 & 23 & 102 \\
\hline $\mathbf{1 9 5 9}$ & 77 & 34 & 41 & 22 & 42 & 88,6 & 30 & 45 & 18 & 19 & 72 & 76 & 41 & 22 & 92 \\
\hline $\mathbf{1 9 6 1}$ & 80 & 32 & 34 & 21 & 37,3 & 88,7 & 26 & 41 & 17 & 18 & 54 & 69 & 32 & 21 & 82 \\
\hline $\mathbf{1 9 6 3}$ & 91 & 27 & 31 & 21,8 & 31,7 & 73,1 & 25,8 & 40 & 16 & 17 & 49 & 55 & 31 & 20 & 78 \\
\hline $\mathbf{1 9 6 5}$ & 87 & 24 & 25 & 19,6 & 29,4 & 64,9 & 22,4 & 36 & 14 & 17 & 42 & 44 & 27 & 18 & 72 \\
\hline $\mathbf{1 9 6 7}$ & 0 & 23 & 21 & 18,8 & 26,1 & 59,2 & 20,8 & 33 & 13 & 15 & 38 & 47 & 26 & 17 & 61 \\
\hline $\mathbf{1 9 6 9}$ & 0 & 23 & 20 & 18,6 & 30 & 55,8 & 19,7 & 30 & 13 & 14 & 34 & 55 & 26 & 15 & 56 \\
\hline
\end{tabular}

In 1952, the Portuguese child mortality rate was considered the worst in Western Europe, were some assistance was provided during the pre-natal period to a small number of pregnant women. Maternal mortality was caused by the lack of assistance provided to women during pregnancy, deliver and post-natal.

Greece Bulgaria Denmark Finland Sweden Portugal

$\begin{array}{lcccccc}\mathbf{1 9 4 7} & 0 & 130 & 40 & 59 & 25 & 107,26 \\ \mathbf{1 9 4 9} & 42 & 116 & 34 & 48 & 23 & 114,5 \\ \mathbf{1 9 5 1} & 44 & 108 & 29 & 35 & 22 & 89,1 \\ \mathbf{1 9 5 3} & 45 & 81 & 27 & 34 & 19 & 95,68 \\ \mathbf{1 9 5 5} & 44 & 82 & 25 & 30 & 17 & 90,24 \\ \mathbf{1 9 5 7} & 44 & 66 & 23 & 28 & 18 & 87,97 \\ \mathbf{1 9 5 9} & 41 & 56 & 22 & 24 & 17 & 88,6 \\ \mathbf{1 9 6 1} & 40 & 38 & 22 & 21 & 16 & 88,7 \\ \mathbf{1 9 6 3} & 39 & 36 & 19 & 18 & 15 & 73,1 \\ \mathbf{1 9 6 5} & 34 & 31 & 19 & 18 & 13 & 64,9 \\ \mathbf{1 9 6 7} & 34 & 33 & 16 & 15 & 13 & 59,2 \\ \mathbf{1 9 6 9} & 32 & 31 & 15 & 14 & 12 & 55,8\end{array}$

Table 2: Compared evolution of child mortality rate in several European countries (1947-1969) - per mileage

[Source: B.R. Mitchell.European Historical Statistics 1750-1970]. 
According to O.C.D.E. data, available only from the 1960s, we can confirm that Portugal was the European country with the highest maternal mortality rate, despite the trend to decrease during this decade. However, our country, with regards to this key sanitary indicator, was way behind the majority of Western Europe [16].

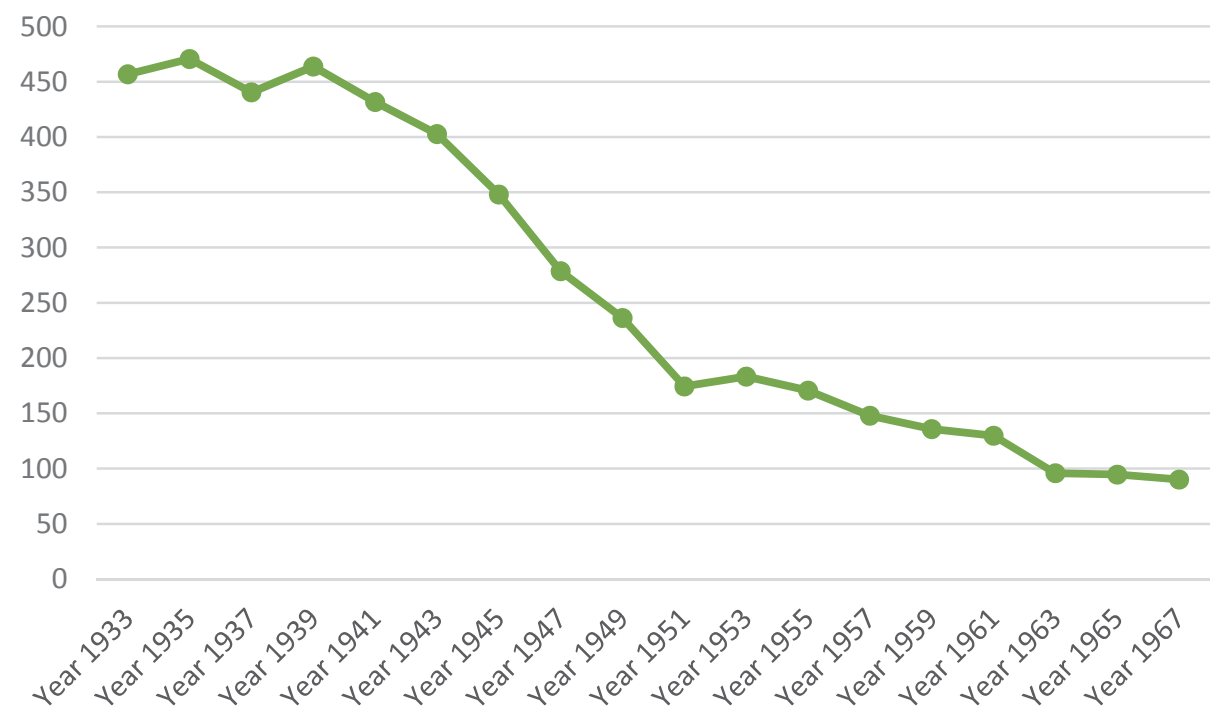

Graphic 9: Evolution of maternal mortality rate per 100.000 inhabitants (1933-1967) [Source: Portuguese Statistics Yearbooks (1933-1967)].

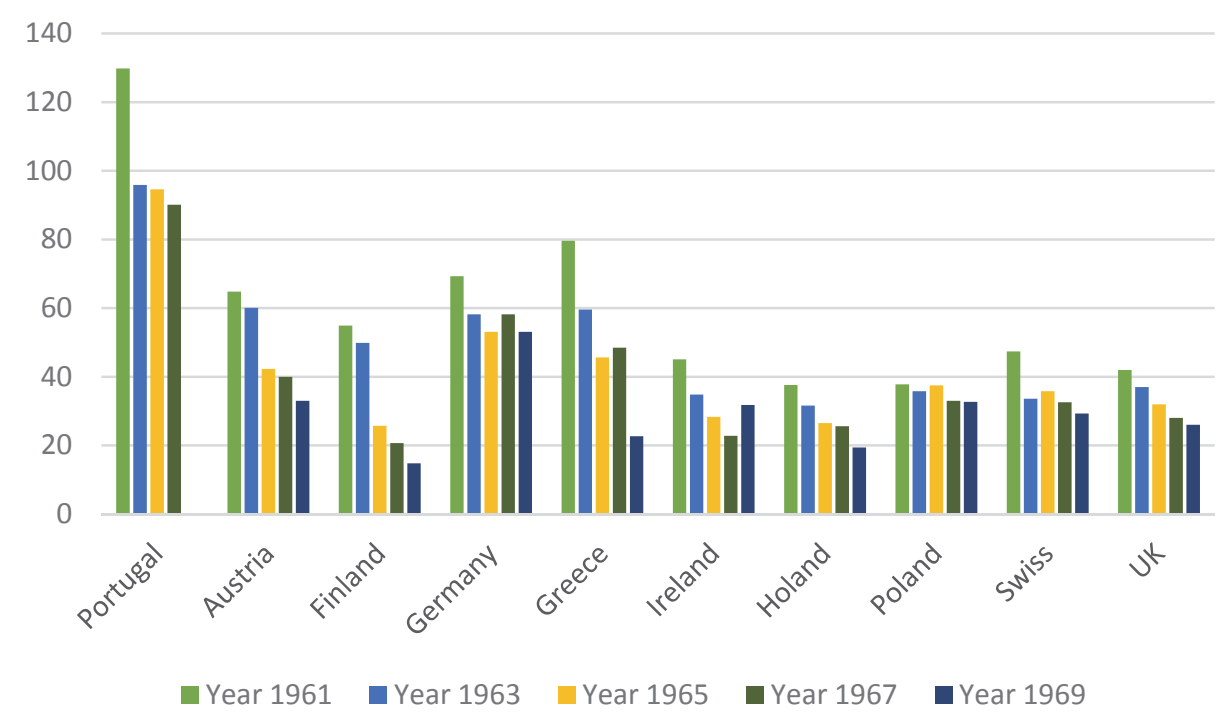

Graphic 10: Compared evolution of maternal mortality rate in some O.C.D.E. European members (1961-1969)

[Source: OECD. OECD.Stat. Health Status: Maternal and Infant Mortality]. 
From the state's financial point of view for maternal and early childhood, we can observe a growing financial support in this area, being reinforced from 19571958, a period of severe crisis in the regime, and that would be consolidated during the 1960s, period after which a considerable drop in this financial support occurred, from 1967 [17]. Nevertheless, no data was found relative to the 1930s, but we assume that there was very little financial support from the state at this level. Between 1943 and 1967, the investment from the state's budget for maternal-infant assistance welfare grew fivefold.

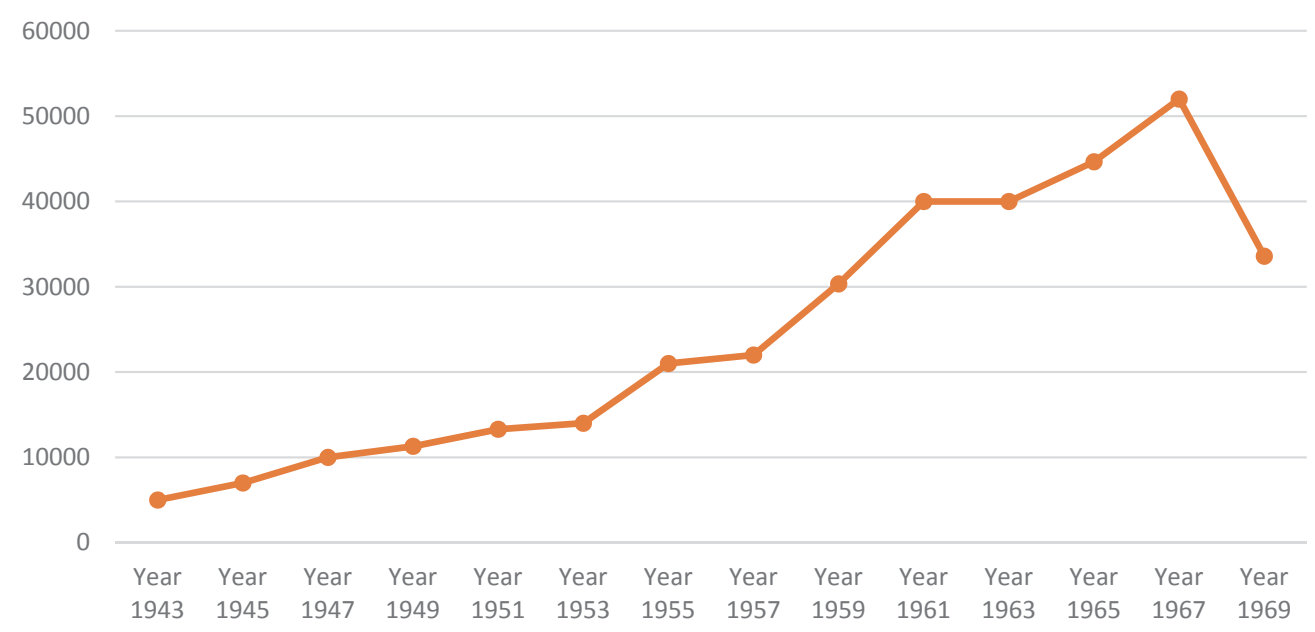

Graphic 11: Evolution of state financing for maternal and infant welfare (1943-1969), through the budget of General Management Assistance - in "contos" (a thousand of "escudos": portuguese currency)

[Source: Portuguese State General Budgets (1943-1969)].

In order to establish a comparison degree between State budget for maternity and infant welfare assistance, and the total budget expense for general welfare assistance, we can analyse the data in Graph. 12 - between 1943 and 1969, the expense with materno-infant welfare assistance would never go over 60.000 contos, registered in 1967, as opposed to the expense with total welfare assistance that would grow exponentially, reaching the 600.000 contos in 1961. In fact, there is almost an unchanging proportion between the budget values for materno-infant welfare assistance, in relation to the total welfare expense, around 5\% to 6\%, between 1943 and 1961. This proportion would only grow during the 1960s, when there was a huge cut in the total state expense with welfare services, being 10,6\% of the total budget between 1963 and 1965, and 30\% in 1967 [17]. 


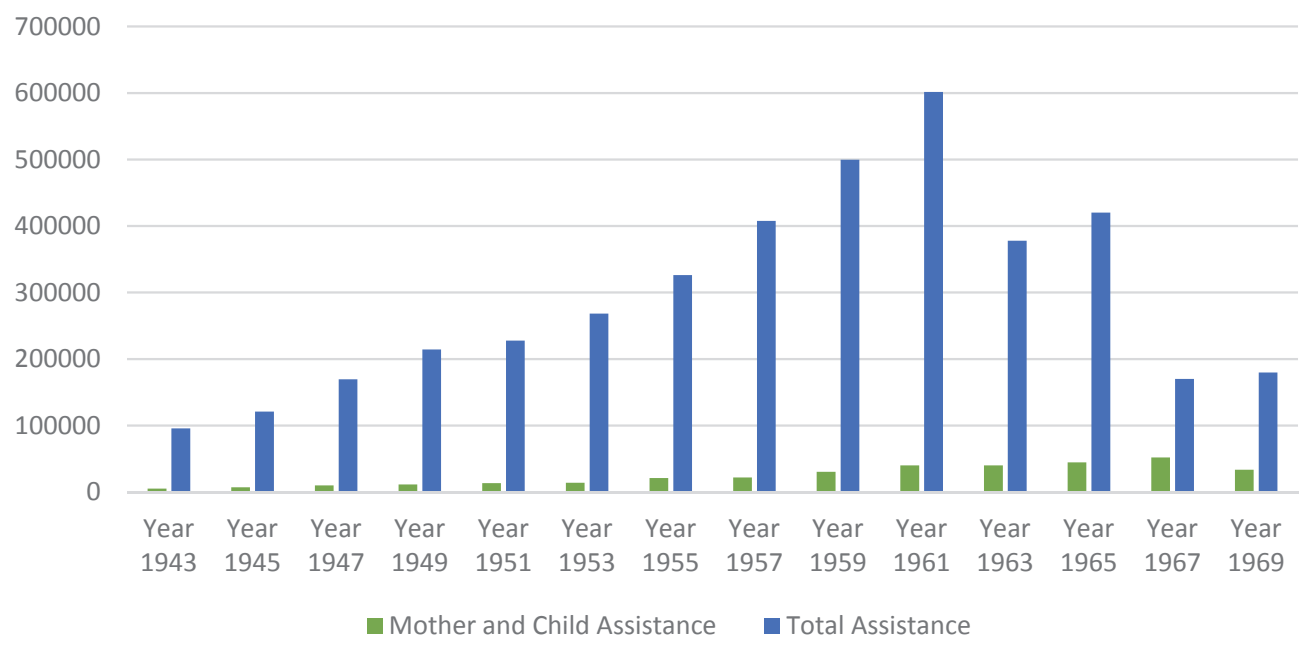

Graphic 12: Compared evolution of budget expense between materno-infant welfare assistance and total public welfare assistance services (1943-1969) - in "contos"

(Portuguese currency)

[Source: Portuguese State General Budgets (1943-1969)].

\section{Discussion}

Francisco Fernandes Homem, Alcântara (Lisbon) Mother and Child Dispensa$r y$ director,gives us some clues that might help explain these discrepancies between infant and maternal mortality high rates in hospital deliveries and nurse and doctor assisted home deliveries. In his article "Positive Norms in Childcare Work", from 1945 , he explains these data with the existence of several "error factors". Maternities and General Hospitals were places where, according to the author, the worst cases of the whole country would be sent to. Often, patients would arrive in "total agony", either due to late hospital submission or, frequently, after several local failed medical resolution attempts. Adding to this scenario, were the slow means of transportation that were available to most of the population, and wouldn't allow for a quick intervention. In the same way, Hospitals would receive women that would provoke their own abortions, with a high rate of risk of infections [18 p237].

Also, the author considered that other error factor should reside in the cause of death registry. In Hospitals, a notification was rigorous and "impersonal", as opposed to clinics, where "there would be a more benevolent subterfuge" [18 p237]. As we can see, the author assumes that the data could have been altered, especially the one of home delivery, hence having more favourable results to the politics that favoured home delivery, as encouraged by the Estado Novo. If, on one hand, a higher materno-infant mortality rate in hospitals due to late intervention made sense, on the other we, like the author, cannot overlook a possible misreading of data by the authorities for their own purposes. 
If the numbers of home deliveries versus hospital deliveries could be explained like this, so can the numbers of unassisted deliveries versus doctor or nurse assisted deliveries. It is obvious that the reduced number of stillborns in unassisted deliveries can be explained, in part, by the fact that some deliveries didn't require assistance, but also by an absence of registries, which was favourable to the authorities. The highest mortality in assisted deliveries, was due to the doctor being called only in the most serious cases, instead of the midwife, present from the beginning, especially in families with more money, thus capable of paying to have professionals with the best reputation.

These data supported the idea, that no adequate hospital training for materno-infant assistance was necessary, because, as Francisco Fernandes Homem stated, "the statistics of home delivery are not worse than the one of Maternities" [18 p237]. According to the author, maternities should be used to cover for home delivery failures, to resolve and study complicated clinical cases, support pregnant women social excluded, thus limiting maternity admission to normal pregnant women.

Francisco Fernandes Homem explains how the whole process took place, from the dispensaries, whenever they existed. Around the $8^{\text {th }}$ pregnancy month, the midwife-nurse would visit the mother to be, to provide all the corresponding socialeconomic information, checking the home for the adequate conditions for home delivery. After this evaluation, the results would be passed on to the doctor, that would then decide if the birth could or not take place at home. As the moment of the delivery would be closer, the midwife was called by the woman's family. The midwife would assist the birth, but could not spontaneously perform parenteral administration of medicine. Should complications occur, the doctor of the dispensary would be called, in order to take over the responsibility and direction of treatment. However, in the most serious cases, where an urgent intervention was required, the immediate admission to a maternity was necessary, thus the pregnant woman would be taken to the maternity by the midwife [18 p240].

We can observe a political, doctrinal and accomplishments policy, in terms of materno-infant assistance during Salazar's regime. In doctrinal terms, Salazar's Estado Novo kept its natalist doctrine, conservative and catholic, condemning abortion, contraceptive methods, the presence of women in the active work force, and defending home child-birth. Everything with a moral and economic dimension.

In political terms, the state entities created for maternity support could not cope with the necessities, did not evolve and even lost its influence throughout the time. Also, these moments of welfare promotions took place during times of crisis, such as, WWI, pots elections of 1958, and the troubled times that afterwards, both in the Continent and its Colonies.

In 1944, The Social Welfare Assistance Status legislated a state materno-infant welfare assistance that would become different from all the other types of assistance, for which the State considered its action as supplementary of private assistance. However, this nationalization would never leave the paper. The State would keep its sup- 
plementary action with the Charities. Most Portuguese children were born at home, without any type of specialized assistance. Hospital child-birth occurred mainly in child-birth infirmaries of hospitals part of the Charities, these being the main centres for specialized child-birth assistance and not the maternities. We can see, however, a progressive increase in the offer and search for this type of institutions, as opposed the decrease of the doctrine.

There was also, a lack of equality between districts with regards to maternoinfant welfare centres. In the same way, there was a lack of human resources, namely midwifesand doctors in general hospitals and maternities. This doctrine and this policy of the Estado Novo produced a reduction in the child mortality rate, although insufficient when compared with the other European countries. This doctrine and policy also produced one of the highest maternal and child under 5 mortality rates in Europe, due to illnesses of the digestive tract, post birth complications and respiratory illnesses.

These indicators are proof that Salazar's Estado Novo policy for materno-infant welfare assistance was insufficient. The regime registered a minimal state investment in this area, when compared with the total welfare investments. An onerous assistance, partly financed by the users and their families, according to their income, at a time where social services provided limited services of materno-infant assistance. Critics came forward against this situation from the opposition - Portuguese Communist Party - and from a medical class less compromised with the Estado Novo.

We can thus conclude, by a large inconsequence between ideology and practice put in place by the regime, both at a health policy and welfare assistance level, during Salazar's presidency of the Council. This incoherence was felt in many levels.

Another great incoherence, was the defence of a natalist policy. This study proves, on the contrary, a clear disinvestment of the Estado Novo in woman and child healthcare. By becoming the major coordinator of materno-infant welfare assistance, the regime never took on its obligations, thus always being a supplement to the Charities, private institutions, providence and luck, where most of pregnant women were abandoned, without any type of assistance. Salazar's regime never considered materno-infant assistance as a priority, thus blaming mothers for the high child mortality rates, blaming them for working away from home. Women were the escape goat of the extremely deficient policy at this level. In the same way, hospital assistance to children was minimal, just like school health, only available for an elite. The Estado Novo, whose catholic and conservative doctrine promoted the family as a main pillar of society, was a regime that tolerated prostitution, only prohibited in the 1960s.

Given the social mutation occurred in the 1960s, where the search for hospital assistance from citizens of all levels of social classes grew, a bigger awareness from the population, their right to health and assistance, the regime was forced to take on an active role, thus making private initiatives supplementary. This was an adaptation of the regime to the new times. However, the political practice evolved, but the ideology remained. The Estado Novo was still defending its action as supplementary to the 
private initiative, condemning women in the work force, as more and more women had to work away from home, still defended home child-birth, as more women opted for medically assisted child-birth, still defended a natalist doctrine, as more women had access to birth control methods. In the 1960s, apart from being demagogical, the Estado Novo was ideologically away from its time.

\section{Rezime}

Portugalska zdravstvena politika je tokom trajanja Salazarovog režima (Estado Novo) odražavala njegove opšte svetonazore. Kriza tokom Drugog svetskog rata i politička previranja u vreme predsedničkih izbora održanih 1958. godine uticali su na razvoj državnog zdravstvenog sektora. Međutim, na planu nege majke i deteta, ideologija i politička praksa nisu bili u korelaciji. Na ideološkom planu, Estado Novo je zauzimao konzervativnu, katoličku i natalističku poziciju, osuđujući abortus, kontracepciju i rad žene van kuće. Portugalske žene, bez obzira da li su bile udate ili ne, trebale su da budu ograničene na ulogu domaćice. Režim je iz ekonomskih i moralnih razloga zastupao porođaj kod kuće, kao minimalistički koncept zdravstvene brige. Porođaji u bolnicama su bili dozvoljeni pre svega majkama iz siromašnih porodica, kao i onima koje su imale komplikovanu trudnoću ili porođaj.

Uprkos retoričkom zalaganju za porodične vrednosti, Salazarov režim nije iskazao preteranu brigu za zdravstvenu zaštitu majke i deteta, niti je za to obezbedio sredstva, što se može videti iz statističkih i budžetskih izvora. Ovaj nedostatak interesovanja i sredstava rezultovao je vrlo visokom smrtnošću novorođenčadi i porodilja. Zdravstvo je uvek zavisilo od donacija i privatnih organizacija, iako je režim formalno istupao kao promoter zdravstvene nege majke i deteta. Političke, društvene i promene mentaliteta tokom šezdesetih godina u Portugalu su iznudile veće prisustvo države u zdravstvu. Međutim, njena uloga u zdravstvenoj zaštiti majke i deteta ostala je na niskom nivou - ona je i dalje zavisila od dobrotvornih institucija i milosrđa.

\section{References}

1. Carneiro M. Ajudar a Nascer: Parteiras, saberes obstétricos e modelos de formação (século XV-1974) [Helping children to be born: Midwifes, obstetric knowledges and training models (XV century -1974)]. Porto: Universidade do Porto; 2008.

2. Bernabeu-Mestre J. Madres y enfermeras. Demografía y salud en la política poblacionista del primer franquismo, 1939-1950 [Mothers and nurses. Health and demographics in the natalist policy of the Francoism 1939-1950]. Rev Demogr Hist. 2002;20(1).

3. Decreto-Lei no. 25936. Diário do Governo [Government Gazette]. I. 1935. 237

4. Parecer 9/III: Estatuto da Assistência Social [Act 9/III of the Corporative Hall: Social Security Status]. Suplemento do Diário das Sessões da Assembleia Nacional. 1944;39.

5. Pessoa AM. A Educação das Mães e das Crianças durante o Estado Novo: a Proposta de Maria Lúcia Vassalo Namorado [Mothers and Childs Education during Estado Novo: the Maria Lúcia Vassalo Namorado’s proposal]. Lisboa: Universidade de Lisboa; 2005. 
6. Oliveira, IC. Associação Protectora da Primeira Infância: Uma História Centenária [Association for the Protection of the First Infancy: a centenary History]. Lisboa: Fundação Aboim Sande Lemos; 2015.

7. Instituto Nacional de Estatística. Anuário Estatístico de Portugal [Portuguese Statistics Yearbook]: Ano [1947-1969]. Lisboa: Imprensa Nacional; [1948-1970].

8. Instituto Nacional de Estatística. Anuário Estatístico de Portugal [Portuguese Statistics Yearbook]: Ano [1957-1965]. Lisboa: Imprensa Nacional; [1957-1965].

9. Instituto Nacional de Estatística. Anuário Estatístico de Portugal [Portuguese Statistics Yearbook]: Ano [1945-1967]. Lisboa: Imprensa Nacional; [1946-1968].

10. Presidência do Conselho de Ministros. Plano Intercalar de Fomento para 1965-1967 [Intercalate Fomenting Plan for 1965-1967]. Lisboa: Imprensa Nacional; 1964.

11. Presidência do Conselho de Ministros. III Plano de Fomento para 1968-1973 [III Fomenting Plan for 1968-1973]. II. Lisboa: INCM; 1968.

12. Bird ST, Bauman KE. State-level infant, neonatal and postneonatal mortality: the contribution of selected structural socioeconomic variables. Int J Health Serv. 1998;28.

13. Braga, M. A Acção das Misericórdias, das Casas do Povo e dos Centros Paroquiais de Assistência no Combate à Mortalidade Infantil [The role of charities, corporative institutions and assistance parish centers in the fight against child mortality]. In: Actas do IV Congresso das Misericórdias. I. 1959 Lisboa (Portugal). Lisboa: c1959. p.33-34.

14. Instituto Nacional de Estatística. Anuário Estatístico de Portugal [Portuguese Statistics Yearbook]: Ano [1933 - 1969]. Lisboa: Imprensa Nacional; [1934-1970].

15. Mitchell BR. European Historical Statistics 1750-1970. London: Macmillan Press; 1978.

16. OECD. OECD.Stat. Health Status: Maternal and Infant Mortality. [Internet], [cited 2016 February 24]. Available from: http://stats.oecd.org/

17. Leis, Decretos. Orçamento Geral do Estado para o Ano Económico de [1943-1969] [Portuguese State General Budget for the Economic Year of...]. Lisboa: Imprensa Nacional; [1944-1970].

18. Homem FF. Normas positivas em trabalhos de puericultura [Positive Norms in Childcare Work]. Boletim da Assistência Social. 1945 Jul/Aug;29-30.

Submitted: 20. 10. 2017.

Reviewed: 29. 10. 2017.

Accepted: 02. 11. 2017. 